\title{
Response of snap bean cultivars of determined growing to inoculation with Rhizobium tropici
}

\section{Resposta de cultivares de feijão-vagem de crescimento determinado à inoculação com Rhizobium tropici}

\author{
Karen Andreon Viçosi \\ Universidade Estadual de Goiás, Câmpus Sudeste, Unidade Universitária de Ipameri \\ E-mail: karen vicosi@hotmail.com \\ OrclD: 0000-0002-9434-1564 \\ Nei Peixoto \\ Universidade Estadual de Goiás, Câmpus Sudeste, Unidade Universitária de Ipameri \\ E-mail: nei.peixoto48@gmail.com \\ OrcID: 0000-0003-2319-8139 \\ Adilson Pelá \\ Universidade Estadual de Goiás, Câmpus Sudeste, Unidade Universitária de Ipameri \\ E-mail: adilson.pela@ueg,br \\ OrclD: $\underline{0000-0002-4742-2468}$
}

\begin{abstract}
The biological nitrogen fixation is a process biological performed by legumes, through symbiotic with bacteria. However, in crop of snap bean, the process is not efficient, wherein some efficient cultivars may be responsible for inoculation. The objective was to evaluate the behavior of seven cultivar bean cultivars determined growing in relation to the inoculation with Rhizobium tropici. The experiment was carried out in the DIC, with four replicates, in the factorial 7x2, corresponding to seven cultivars of bean-pod of determined growth (Commodore Improved, Contender, Delinel, Jade, Strike, Stringless Green and Provider), in the presence and absence of rhizobian inoculum ( $R$. tropici). The height, diameter, number of leaves, leaf area, dry mass of the aerial part were evaluated at the flowering stage; length, area, root dry mass; the number of nodules; nitrogen content, accumulated nitrogen, nitrogen utilization efficiency, specific nodulation, and relative efficiency. The use of $R$. tropici does not interfere in the vegetative development of the aerial part of the bean pod until the flowering phase. The cultivars Delinel, Jade and Stringless Green stand out when nodulation. The inoculation negatively affects the nitrogen and nitrogen contents accumulated by the aerial part, but it is able to increase the number of nodules, specific nodulation and the efficiency of nitrogen utilization. There is a negative correlation between the nodulation and the dry mass of the aerial part, nitrogen content and the nitrogen accumulated by the aerial part.
\end{abstract}

Keywords: Phaseolus vulgaris, biological nitrogen fixation, rhizobia, nodulation, nitrogen utilization efficiency

Resumo: A fixação biológica de nitrogênio é um processo biológico realizado por leguminosas, através da simbiose com bactérias. Entretanto, na cultura do feijão-vagem, o processo não é eficiente, sendo que algumas cultivares eficientes podem ser responsivas à inoculação. O objetivo foi avaliar o comportamento de sete cultivares de feijão determinadas em crescimento em relação à inoculação com Rhizobium tropici. O experimento foi realizado no DIC, com quatro repetições, no fatorial 7x2, correspondendo a sete cultivares de vagem de feijão de crescimento determinado (Commodore Improved, Contender, Delinel, Jade, Strike, Stringless Green and Provider), na presença e ausência de inóculo rizóbio ( $R$. tropici). A altura, diâmetro, número de folhas, área foliar, massa seca da parte aérea foram avaliadas na fase de floração; comprimento,

Agrarian, Dourados, v. 13, n. 49, p. 352-361, 2020. 
área, massa seca da raiz; o número de nódulos; teor de nitrogênio, nitrogênio acumulado, eficiência na utilização de nitrogênio, nodulação específica e eficiência relativa. O uso de $R$. tropici não interfere no desenvolvimento vegetativo da parte aérea da vagem até a fase de floração. As cultivares Delinel, Jade e Stringless Green destacam-se quando da nodulação. A inoculação afeta negativamente o nitrogênio e o conteúdo de nitrogênio acumulado pela parte aérea, mas é capaz de aumentar o número de nódulos, a nodulação específica e a eficiência da utilização do nitrogênio. Existe uma correlação negativa entre a nodulação e a massa seca da parte aérea, o teor de nitrogênio e o nitrogênio acumulado pela parte aérea.

Palavras-chave: Phaseolus vulgaris, fixação biológica de nitrogênio, rizóbio, nodulação, eficiência na utilização de nitrogênio

Data de recebimento: 03/09/2019

Data de aprovação: 18/05/2020

DOI: https://doi.org/10.30612/agrarian.v13i49.10335

\section{Introduction}

Snap bean (Phaseolus vulgaris L.) is a horticultural legume, of great nutritional and economic importance, in which its pods are consumed in the immature form, rich in essential vitamins (A, B12 and C), minerals and fibers, an excellent source of nutrients for human consumption (Filgueira et al., 2013).

The snap beans are a nodulation Fabaceae capable of establishing mutual symbiotic with bacteria Rhizobiacea family, naturally present in the soil or by seed inoculation, and thus benefit from nitrogen fixed in a process called biological nitrogen fixation (BNF) (Matoso e Kusdra, 2014). Among the many bacteria that are able to establish symbiosis with snap beans, Rhizobium tropici is the most suitable type and recommended for tropical soils, because of its large capacity nodulation and their high tolerance to environmental stresses such as high temperature, acidity, and salinity (Cerro et al., 2017).

Despite the numerous benefits of biological fixation for legumes, there is still little research on this process for snap beans, which makes it inefficient in the accumulation of nitrogen in the plant, making the crop is dependent on mineral nitrogen sources. Considering that the inoculation technique with rhizobia, by itself, is not fully efficient for culture, it is necessary to study alternatives to increase the efficiency of BNF and benefit mainly small farmers (Bertoldo et al., 2015).

An alternative to improve BNF efficiency would be an evaluation of genotypes, and there is a great variety among cultivars regarding the number of nodules and the accumulation of nitrogen by the common bean. (Fonseca et al., 2013). Currently, the search for more efficient cultivars in the use of nitrogen (NUE) is one of the main objectives of several programs of genetic improvement of different cultures, with the purpose of reducing the amount of nitrogen applied, without damaging gains in grain yield (Barraclough et al. 2014). Thus, the NUE studies on the available genotypes are important to update and print the technologies most adapted to the producer, bringing economically satisfactory yields with less risk of environmental pollution (Teixeira Filho et al., 2010).

Although the bean pod is considered to be of low efficiency in the BNF, Furlan et al. (2016) obtained promising results when studying the effects of inoculation on the crop, being a viable alternative and less onerous to improve the yield of the pods of the bean pod. Therefore, it is indispensable to disseminate this very low-cost biotechnology, considering that biological nitrogen fixation is an ecological, economically advantageous and sustainable process (Chagas Junior, 2010). Therefore, the aim of this study was to evaluate the behavior of seven cultivars of snap beans of growth determined in relation to the inoculation with Rhizobium tropici.

\section{Material and Methods}

Location and characterization of the experimental area

Agrarian, Dourados, v. 13, n. 49, p. 352-361, 2020. 
The experiment was carried out in a greenhouse belonging to the State University of Goiás, Câmpus Ipameri, with geographic coordinates of $17^{\circ} 9^{\prime} 59^{\prime \prime} \mathrm{W}$ and $48^{\circ} 26^{\prime} 34^{\prime \prime} \mathrm{S}$, an altitude of approximately 800 meters. The weather is considered Aw, characterized in a tropical humid climate with dry winter and summer rainy second Koppen classification (Alvares et al., 2013).

The soil was collected in the arable layer $(0-20 \mathrm{~cm})$ of a LATOSOLO VERMELHO Distrófico (Santos et al., 2018), in which it was dewormed, homogenized and passed in a $4 \mathrm{~mm}$ sieve and placed in vessel nine liters. Prior to the installation of the experiment, the soil had the following chemical and physical parameters: $\mathrm{pH}-\mathrm{CaCl}_{2}$ 5.1; clay $300 \mathrm{~g} \mathrm{~kg}^{-1}$; $\mathrm{Ca}, \mathrm{Mg}$ and $\mathrm{Al}, 2.8,1.8$ and $0 \mathrm{mg} \mathrm{dm}^{-3}$, respectively (extracted by $\mathrm{KCl} 1 \mathrm{~mol} \mathrm{~L}^{-1}$ ); $\mathrm{P}$ and K available 4.7 and $78 \mathrm{mg} \mathrm{dm}^{-3}$, respectively (extracted by Mehlich-1), organic matter $28.0 \mathrm{~g} \mathrm{~kg}^{-1}$, according to Teixeira et al. (2017).

\section{Treatments and experimental design}

The experiment was carried out in a completely randomized design, with four replications, in the $7 \times 2$ factorial scheme corresponding to seven cultivars (Commodore Improved, Contender, Delinel, Jade, Strike, Stringless Green, and Provider) in the presence and absence of rhizobial inoculant (Rhizobium tropici).

The inoculant used was Nitro1000 Feijão, from the company Nitro1000, in the form of liquid fluid containing 3,0 $\times 10^{9}$ viable cells per $\mathrm{mL}$ of Rhizobium tropici Semia 4077 and Semia 4088, in the dose of 100 $\mathrm{mL}$ to $40 \mathrm{~kg}$ of seeds. The inoculation was carried out during planting, being mixed directly in the seed.

\section{Installation and conduction of the experiment}

Planting fertilization it was made with $50 \mathrm{~kg} \mathrm{ha}^{-1}$ of $\mathrm{N}, 300 \mathrm{~kg} \mathrm{ha}^{-1}$ of $\mathrm{P}_{2} \mathrm{O}_{5}$ and $100 \mathrm{~kg} \mathrm{ha}^{-1}$ of $\mathrm{K}_{2} \mathrm{O}$, using as the source using ammoniated superphosphate (03-17-00) and potassium chloride $\left(60 \% \mathrm{~K}_{2} \mathrm{O}\right)$.

During the conduction of the experiment, daily irrigation was carried out until reaching the field capacity, in order to keep soil moisture constant, in addition to manual weed withdrawal. The experiment was carried out to the phenological stage R6 (flowering).

\section{Variables evaluated in the experiment}

In the aerial part, the height (HEI) was measured through a millimeter ruler; diameter (DIAM) through digital caliper; and the number of leaves $(\mathrm{NL})$, by manual counting of triphols. Afterward, the aerial part of the plants was collected, cutting them close to the soil and taken to the laboratory for determination of the leaf area (LA) and dry mass of the aerial part (DMAP).

The roots were carefully washed in water for removal of the soil adjacent to the roots, with posterior measurement of root length (RL) with millimeter ruler, the number of nodules $(N N)$ by manual counting; root area (RA) and dry mass of root (DMR).

The leaf area and root area were obtained by scanning the HP Scanjet G2410 scanner and the images were processed Image $\mathrm{J}$. The dry matter of the aerial part and the root system was dried in an oven with forced air circulation at a temperature of $65^{\circ} \mathrm{C}$ until obtaining of constant mass, for later weighing in a digital scale.

For the evaluation of the nitrogen content in the aerial part (NCAP), the dry mass of the shoot was used, which after being weighed, were milled in the Willye Macro Mill with 30 mesh sieves. Then, the nitrogen content according to the Kjeldahl method, which consists of the sulfuric digestion + distillation + titration according to the methodology described in Carmo et al. (2000).

Subsequently, it was calculated the nitrogen accumulated in the aerial part (ANAP), result of the product of NCAP and DMAP, and nitrogen utilization efficiency (NUE) obtained by the formula: NUE $\left(g^{2} \mathrm{mg}-1\right)=$ dry mass of the aerial part ${ }^{2} /$ accumulated nitrogen in aerial part, adapted from Siddiqi and Glass (1981).

The specific nodulation (SN), through the expression $\mathrm{SN}=$ (number of nodules / DMR), and the relative efficiency (RE), calculated according to the formula RE = (DMAP inoculated / DMAP without inoculation) $\times 100$, in which DMAP is the dry matter of the aerial part of the plant. 


\section{Statistical analysis}

The data were submitted to analysis of variance, and when significant, the means were compared by the Scott-Knott test at $5 \%$ probability, and then the Pearson correlation was calculated between the variables, both through software R.

\section{Results and Discussion}

The aerial part variables were not influenced by the inoculation or interaction with the cultivar $\mathrm{x}$ inoculum, although they are important for the effect of the cultivars. The Contender cultivar presented higher values for these variables, demonstrating greater shoot growth capacity. Note that that use from $R$. tropici does not interfere in the vegetative development of the aerial part of the bean pod until the flowering phase.

Table 1. Analysis of variance and test of averages of height (HEI), diameter (DIAM), number of leaves (NL), dry mass of aerial part (DMAP), leaf aerial (LA), root length (RL), root dry mass (DMR), number of nodules (NN) and specific nodulation (SN) in different cultivars, in the absence and presence of inoculation with Rhizobium tropici

\begin{tabular}{|c|c|c|c|c|c|c|c|c|c|c|}
\hline \multirow[b]{2}{*}{ Cultivar } & $\mathrm{HEI}$ & DIAM & $\mathrm{NL}$ & DMAP & LA & $\mathrm{RL}$ & RA & DMR & NN & $\mathrm{SN}$ \\
\hline & $(\mathrm{cm})$ & $(\mathrm{mm})$ & $\left(n^{\circ}\right)$ & (g) & $\left(\mathrm{cm}^{2}\right)$ & $(\mathrm{cm})$ & $\left(\mathrm{cm}^{2}\right)$ & (g) & $\left(\mathrm{n}^{\circ} \mathrm{pl}^{-1}\right)$ & $\begin{array}{c}\left(n^{0} m s r\right. \\
1)\end{array}$ \\
\hline $\begin{array}{c}\text { Commodore } \\
\text { I. }\end{array}$ & $\begin{array}{c}25,24 \\
b\end{array}$ & 4,78 & $5,43 a$ & $3,38 \mathrm{~b}$ & 471,28 & $38,06 \mathrm{~b}$ & $112,68 b$ & $0,42 a$ & 48,25 a & $112,27 b$ \\
\hline Contender & $\begin{array}{c}29,42 \\
a\end{array}$ & 5,15 & $5,87 a$ & $4,12 \mathrm{a}$ & 420,04 & $39,19 \mathrm{~b}$ & $152,94 a$ & $0,66 a$ & 63,62 a & $97,86 \mathrm{~b}$ \\
\hline Delinel & $\begin{array}{c}31,86 \\
a\end{array}$ & 4,81 & $4,44 \mathrm{~b}$ & $3,13 b$ & 275,18 & 48,56 a & $151,15 a$ & 0,56 a & 46,25 a & $76,67 \mathrm{~b}$ \\
\hline Jade & $\begin{array}{c}26,23 \\
b\end{array}$ & 4,89 & $5,62 \mathrm{a}$ & $2,49 \mathrm{~b}$ & 420,18 & 44,75 a & $128,75 \mathrm{~b}$ & $0,55 a$ & 74,25 a & $143,97 a$ \\
\hline Provider & $\begin{array}{c}28,95 \\
a\end{array}$ & 4,82 & $5,12 \mathrm{~b}$ & $3,03 \mathrm{~b}$ & 405,59 & $37,50 \mathrm{~b}$ & $108,73 \mathrm{~b}$ & $0,39 \mathrm{~b}$ & $59,00 \mathrm{a}$ & $185,56 a$ \\
\hline Strike & $\begin{array}{c}25,30 \\
b\end{array}$ & 4,57 & $4,75 \mathrm{~b}$ & $4,43 a$ & 421,59 & $36,89 \mathrm{~b}$ & $179,41 \mathrm{a}$ & $0,53 a$ & $8,87 \mathrm{~b}$ & $22,74 \mathrm{~b}$ \\
\hline Stringless G. & $\begin{array}{c}31,29 \\
a \\
\end{array}$ & 4,88 & $5,87 a$ & $2,56 \mathrm{~b}$ & 382,97 & 44,06 a & $175,97 \mathrm{a}$ & $0,63 a$ & 58,25 a & $93,35 \mathrm{~b}$ \\
\hline \multicolumn{11}{|l|}{ Inoculation } \\
\hline Absence & 28,05 & 4,78 & 5,19 & 3,35 & 406,31 & 41,07 & 148,13 & 0,53 & $42,07 \mathrm{~b}$ & $83,53 \mathrm{~b}$ \\
\hline Presence & 28,61 & 4,89 & 5,41 & 3,26 & 392,52 & 41,50 & 140,32 & 0,54 & 60,36 a & $125,44 a$ \\
\hline Cultivar & $3,984^{*}$ & 1,202 & $3,338^{*}$ & $6,253^{*}$ & 1,352 & $3,174^{* *}$ & $3,514^{*}$ & $3,864^{*}$ & $4,616^{*}$ & $3,613^{*}$ \\
\hline Inoculum & 0,296 & 0,620 & 0,864 & 0,201 & 0,121 & 0,050 & 0,464 & 0,110 & $6,184^{*}$ & $4,258^{* *}$ \\
\hline $\mathrm{C} \times \mathrm{I}$ & 1,115 & 0,325 & 0,346 & 1,848 & 1,500 & 1,724 & 1,401 & $2,679^{*}$ & 1,528 & 0,549 \\
\hline CV (\%) & 13,83 & 9,28 & 16,26 & 25,18 & 37,12 & 17,28 & 29,79 & 26,18 & 53,72 & 72,74 \\
\hline
\end{tabular}

Within each factor, means followed by the same letter belong to the same group according to the Scott-Knott test (p>0.05). ${ }^{*}$ Significant at $5 \%$ probability. ${ }^{* *}$ Significant at $1 \%$ probability

In relation to plant height, these results corroborate in part with the work of Vaz et al. (2017), in which it verified differences between the heights of tested bean cultivars and affirm that genotypes with greater vigor are desirable, promoting a better initial performance in the field. Although no inoculation effect was observed at plant height, Furlan et al. (2016) observed that inoculation treatments promoted increments in height and diameter of snap beans, as well as improving other agronomic characteristics.

Vieira et al. (2010) found a similar result for the dry mass of aerial part (DMAP), with a difference between the accumulations of biomass among six Macassar bean cultivars, not observing a significant effect of DMAP increase as a function of inoculation. However, Fonseca et al. (2013), in addition to finding differences between 
common bean cultivars, observed higher DMAP in inoculated plants, attributing to the fact the greater efficiency of inoculated strains in providing nitrogen to the bean, with increases of 15 to $20 \%$ in the biomass.

With regard to the variables of the root system, it was found the effect of cultivars analyzed for root length, root area, number of nodes and root dry mass, but only the latter was significantly influenced by the interaction cultivar $\mathrm{x}$ inoculum (Table 1). The highlight is for the cultivars Delinel, Jade and Stringless Green whose performance was superior in most of the variables.

The significant effect of inoculation was observed only for the number of nodules and specific nodulation. In relation to the number of nodules $(\mathrm{NN})$, it was observed that the inoculation with $R$. tropici promoted an average increase of $43 \%$ compared to the treatment in the absence of inoculant in snap bean plants, whereas for the specific nodulation the increase due to inoculation was $50 \%$. This increase in nodulation was found by several studies in the literature, as described by Soares et al. (2016), Fonseca et al. (2013) and Oliveira e Sbardelotto (2011).

The unfolding of interaction in the root dry mass (RDM) and the inoculation effect on the number of nodules and specific nodulation is shown in Table 2. In relation to RDM, the cultivars Contender, Delinel, Strike and Stringless showed higher RDM values in the presence of $R$. tropici, but only Delinel and Stike obtained a significant increase in response to the use of the rhizobium inoculant.

Table 2. Unfolding of the interaction of root dry mass (DMR) and of the inoculant effect on nodule number (NN) and specific nodulation (SN) at different cultivars in the absence and presence of inoculation with Rhizobium tropici

\begin{tabular}{lcccccc}
\hline \multirow{2}{*}{ Cultivar } & \multicolumn{2}{c}{ DMR $(\mathrm{g})$} & \multicolumn{2}{c}{$\mathrm{NN}\left(\mathrm{n}^{\circ} \mathrm{pl}^{-1}\right)$} & \multicolumn{2}{c}{$\mathrm{SN}\left(\mathrm{n}^{\circ} \mathrm{msr}^{-1}\right)$} \\
\cline { 2 - 6 } & Absence & Presence & Absence & Presence & Absence & Presence \\
\hline Commodore I. & $0,40 \mathrm{aB}$ & $0,44 \mathrm{aB}$ & $33,00 \mathrm{a}$ & $63,50 \mathrm{a}$ & $80,56 \mathrm{a}$ & $143,95 \mathrm{a}$ \\
Contender & $0,72 \mathrm{aA}$ & $0,59 \mathrm{aA}$ & $64,50 \mathrm{a}$ & $62,75 \mathrm{a}$ & $90,25 \mathrm{a}$ & $105,49 \mathrm{a}$ \\
Delinel & $0,43 \mathrm{bB}$ & $0,69 \mathrm{aA}$ & $22,75 \mathrm{~b}$ & $69,75 \mathrm{a}$ & $51,12 \mathrm{a}$ & $102,23 \mathrm{a}$ \\
Jade & $0,60 \mathrm{aB}$ & $0,51 \mathrm{aB}$ & $49,50 \mathrm{~b}$ & $99,00 \mathrm{a}$ & $89,39 \mathrm{~b}$ & $198,55 \mathrm{a}$ \\
Provider & $0,45 \mathrm{aB}$ & $0,34 \mathrm{aB}$ & $62,75 \mathrm{a}$ & $55,25 \mathrm{a}$ & $165,18 \mathrm{a}$ & $203,94 \mathrm{a}$ \\
Strike & $0,42 \mathrm{bB}$ & $0,64 \mathrm{aA}$ & $10,00 \mathrm{a}$ & $7,70 \mathrm{a}$ & $32,02 \mathrm{a}$ & $13,45 \mathrm{a}$ \\
Stringless Green & $0,68 \mathrm{aA}$ & $0,58 \mathrm{bA}$ & $52,00 \mathrm{a}$ & $64,50 \mathrm{a}$ & $76,18 \mathrm{a}$ & $143,97 \mathrm{a}$ \\
\hline
\end{tabular}

Within each factor, capital averages in the column and lowercase in the row, followed by the same letter, belong to the same group according to the Scott-Knott test ( $p>0.05)$

The cultivars Delinel and Jade increased the NN in the presence of inoculant, while the others showed no significant increase due to inoculation, whereas only Jade increased the SN.

Note that for all cultivars nodulation occurred in both the presence and absence of the inoculant. This corroborates with the described by Oliveira e Sbardelotto (2011), in which all the bean varieties, even those not inoculated, produced nodules, indicating the presence of native nitrogen-fixing symbionts bacteria in the soil. However, the same authors affirm that nodule formation was less than $50 \%$ when compared to treatments that received inoculant.

It is essential to clarify that despite introducing selected rhizobia by inoculating, it is not excluded the possibility of the native strains present in the soil promote nodulation, except if the inoculation is carried out under artificial conditions of sterilized soil. Therefore, the rhizobia strains of the inoculant should also be efficient enough in the BNF to be able to surpass the native ones, ensuring greater nodulation than these (Matoso e Kusdra, 2014).

Analyzing the cultivars, it was verified that Delinel and Jade increased the nodulation significantly, while they did not vary the function of the inoculation, demonstrating the differentiation between the genotypes. Albuquerque et al. (2012) state that there is variation among bean genotypes in nodulation, which is justified by the higher genetic potential of nodulatory and biological nitrogen fixation of the cultivar, besides the existence of significant variability among the cultivars.

In a study by Chekanai et al. (2018), it demonstrated that there are improved bean cultivars responsive to rhizobium inoculation, and there are soils that are not responsive to this practice, especially those that are

Agrarian, Dourados, v. 13, n. 49, p. 352-361, 2020. 
degraded. Yagi et al. (2015) concluded that there are differences between commercial bean cultivars, with more efficient cultivars in the BNF in the presence of strains of native or exogenous rhizobia, while other cultivars are only responsive to nitrogen fertilization. This fact may have occurred with the cultivar Strike, which was not able to perform satisfactory nodulation.

Overall, the number of nodules was considered acceptable, above 15 units per plant, indicating good symbiotic efficiency, except for the cultivar Strike. However, Fonseca et al. (2013) that the number of nodules should not be analyzed in isolation because many times there is the formation of many nodules of small size.

The nitrogen content of the aerial part (NCAP) and nitrogen accumulated by the aerial part (NAAP) were influenced by the cultivar $\mathrm{x}$ inoculum interaction, but it was observed a lower mean for the variables when submitted to inoculation, with a mean reduction of $20.85 \%$ and of $22.73 \%$ respectively (Table 3 ).

Table 3. Analysis of variance and mean test of the nitrogen content of the aerial part (TNPA), accumulated nitrogen in aerial part (NAPA), nitrogen utilization efficiency (NUE), and relative efficiency (RE) in different cultivars, in the absence and presence of inoculation with $R$. tropici

\begin{tabular}{lcccc}
\hline \multirow{2}{*}{ Cultivar } & $\mathrm{NCAP}$ & ANAP & NUE & RE \\
\cline { 2 - 5 } & $\left(\mathrm{g} \mathrm{kg}^{-1}\right)$ & $\left(\mathrm{mg} \mathrm{planta}^{-1}\right)$ & $\left(\mathrm{g}^{2} \mathrm{mg}^{-1}\right)$ & $(\%)$ \\
\hline Commodore I. & $24,7 \mathrm{a}$ & $87,4 \mathrm{a}$ & $0,13 \mathrm{~b}$ & 71,46 \\
Contender & $24,0 \mathrm{a}$ & $98,3 \mathrm{a}$ & $0,18 \mathrm{a}$ & 102,69 \\
Delinel & $23,0 \mathrm{a}$ & $73,1 \mathrm{~b}$ & $0,14 \mathrm{~b}$ & 101,83 \\
Jade & $22,6 \mathrm{a}$ & $57,5 \mathrm{~b}$ & $0,11 \mathrm{~b}$ & 116,33 \\
Provider & $22,4 \mathrm{a}$ & $67,5 \mathrm{~b}$ & $0,14 \mathrm{~b}$ & 104,62 \\
Strike & $25,8 \mathrm{a}$ & $115,3 \mathrm{a}$ & $0,17 \mathrm{a}$ & 128,83 \\
Stringless G. & $19,6 \mathrm{a}$ & $50,4 \mathrm{~b}$ & $0,13 \mathrm{~b}$ & 113,47 \\
\hline Inoculation & & & & - \\
Absence & $25,9 \mathrm{a}$ & $88,3 \mathrm{a}$ & $0,13 \mathrm{~b}$ & - \\
Presence & $20,5 \mathrm{~b}$ & $68,6 \mathrm{~b}$ & $0,17 \mathrm{a}$ & 0,741 \\
\hline Cultivar & $2,542^{* *}$ & $6,195^{*}$ & $2,588^{* *}$ & - \\
Inoculum & $31,56^{*}$ & $7,875^{*}$ & $7,208^{* *}$ & - \\
C x I & $3,114^{* *}$ & $2,96^{* *}$ & 1,706 & 39,20 \\
\hline CV $(\%)$ & 15,37 & 33,42 & 28,00 & \\
\hline
\end{tabular}

Within each factor, means followed by the same letter belong to the same group according to the Scott-Knott test (p>0.05). ${ }^{*}$ Significant at $5 \%$ probability. ${ }^{* *}$ Significant at $1 \%$ probability

Nitrogen use efficiency (NUE) increased by $29 \%$ in the presence of inoculation, in addition to differentiated behavior among the cultivars, so that Contender and Strike obtained higher efficiencies. There was no difference between the cultivars relative to the relative efficiency (RE), varying between 71.46 and $128.83 \%$. Results similar to those found by Chagas Junior et al. (2010), who did not obtain significance for RE when testing different cultivars, strains and nitrogen fertilization, while Yagi et al. (2015) found ER of beans varying between 91 and $113 \%$, while cultivars inferior to $100 \%$ were classified as efficient and responsive only to nitrogen fertilization.

In relation to the nitrogen content of the aerial part, there was only a differentiation of the cultivars in the presence of the inoculation (Table 4). Strike showed higher mean when inoculated, while Contender, Delinel, Jade and Stringless Green reduced NCAP. 
Table 4. Unfolding of the interaction of the nitrogen content of the aerial part (TNPA), accumulated nitrogen in aerial part (NAPA), and nitrogen utilization efficiency (NUE) in different cultivars, in the absence and presence of inoculation with R. tropici

\begin{tabular}{lcccccc}
\hline \multirow{2}{*}{ Cultivar } & \multicolumn{2}{c}{ NCAP $\left(\mathrm{g} \mathrm{kg}^{-1}\right)$} & \multicolumn{2}{c}{ ANAP $\left(\mathrm{mg}^{2}\right.$ planta- $\left.\mathrm{-}^{-1}\right)$} & \multicolumn{2}{c}{ NUE $\left(\mathrm{g}^{2} \mathrm{mg}^{-1}\right)$} \\
\cline { 2 - 7 } & Absence & Presence & Absence & Presence & Absence & Presence \\
\hline Commodore I. & $27,0 \mathrm{aA}$ & $22,4 \mathrm{aB}$ & $115,5 \mathrm{aA}$ & $57,0 \mathrm{bB}$ & $0,15 \mathrm{a}$ & $0,12 \mathrm{a}$ \\
Contender & $28,4 \mathrm{aA}$ & $19,6 \mathrm{bB}$ & $117,8 \mathrm{aA}$ & $81,1 \mathrm{aB}$ & $0,14 \mathrm{~b}$ & $0,22 \mathrm{a}$ \\
Delinel & $28,5 \mathrm{aA}$ & $17,6 \mathrm{bB}$ & $93,0 \mathrm{aA}$ & $53,2 \mathrm{bB}$ & $0,11 \mathrm{~b}$ & $0,18 \mathrm{a}$ \\
Jade & $25,6 \mathrm{aA}$ & $19,6 \mathrm{bB}$ & $65,9 \mathrm{aB}$ & $49,1 \mathrm{aB}$ & $0,09 \mathrm{a}$ & $0,13 \mathrm{a}$ \\
Provider & $24,7 \mathrm{aA}$ & $20,0 \mathrm{aB}$ & $74,1 \mathrm{aB}$ & $60,8 \mathrm{aB}$ & $0,12 \mathrm{a}$ & $0,15 \mathrm{a}$ \\
Strike & $24,2 \mathrm{aA}$ & $27,5 \mathrm{aA}$ & $94,5 \mathrm{bA}$ & $135,9 \mathrm{aA}$ & $0,17 \mathrm{a}$ & $0,18 \mathrm{a}$ \\
Stringless G. & $22,4 \mathrm{aA}$ & $16,8 \mathrm{bB}$ & $57,4 \mathrm{aB}$ & $43,4 \mathrm{aB}$ & $0,12 \mathrm{a}$ & $0,15 \mathrm{a}$ \\
\hline
\end{tabular}

Within each factor, capital averages in the column and lowercase in the row, followed by the same letter, belong to the same group according to the Scott-Knott test ( $p>0.05)$

For the accumulated nitrogen in the aerial part, there were variations between the cultivars in the absence and the presence of the inoculation, especially Strike, which accumulated more nitrogen in the presence of $R$. tropici, besides presenting the highest average, while Commodore and Delinel reduced the accumulation with the bacteria. For NUE, only Contender and Delinel have increased efficiency.

According to Vieira et al. (2010), the fact that the challenge did not result in $\mathrm{N}$ content ideal for snap beans indicates that symbioses may not have been effective in promoting necessary quantities of nutrients the plant, causing its deficiency during development. In addition, it indicates that the native strains of the soil were able to perform symbiosis with the legume, which can compete and predominate in the soil with the strains introduced by the experiment, even though it is less efficient symbiotically.

Another explanation for the lower leaf nitrogen content, and therefore less accumulation of nitrogen by snap beans in the presence of inoculant, is related to the high-energy demand of BNF. A considerable amount of energy is required to break the triple bond of atmospheric $\mathrm{N}_{2}$ in the molecule with ammonia production in an exothermic reaction, consuming about 12 grams of organic carbon per gram of $\mathrm{N}_{2}$ fixed (Taiz et al., 2017).

Along with the assumptions already mentioned, another factor explaining the low ANAP is at particular growth short cycle of snap bean crop, which makes the apparatus of establishing symbiotic fixation of $\mathrm{N}$ and its efficient operation to provide content nitrogen necessary for the plant (Soares et al., 2016).

The TNPA is indicative of how effective was the absorption and assimilation of N, including through FBN, while the NAPA has been considered as a potential indicator strain with inoculants to compose with symbiotic efficiency (Fonseca et al., 2013). The ANAP is directly proportional to shoot biomass and nitrogen content in the plant, which explains the high accumulation of $\mathrm{N}$ in some cultivars, such as Commodore Improved, Contender and Strike.

Although different behavior of the cultivars for NCAP and ANAP under inoculation, which was not repeated for the nitrogen use efficiency, that despite having an average higher in inoculated plants, only two cultivars were able to increase their efficiency. In addition, in the presence of inoculation, all were statistically the same, not being possible to differentiate them in this variable. According to Cancellier et al. (2011), efficient cultivars in the use of nitrogen are indicated for low technology crops, in which the producers do not use large doses of nitrogen fertilization, due to the high cost of this nutrient.

Regarding the correlation between the analyzed variables, there are differences between the behavior of the uninoculated and inoculated plants. In uninoculated plants (Figure 1A), nine significant positive correlations were observed, where nodulation was influenced only by DMR, while ANAP was influenced by diameter, DMAP, and NCAP. The negative corrections were in the RE, directly affected by height, diameter, DMAP, ANAP, and NUE. 


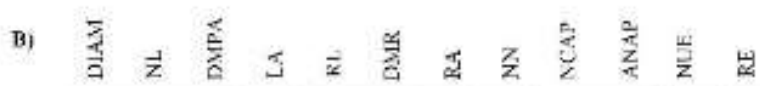

$\begin{array}{lllllllllllll}\text { HEI } & 0,15 & 0,10 & 0,03 & -0,18 & 0,22 & 0,32 & -0,07 & 0,03 & -0,54^{*} & -0,2 & 0,4 * & 0,23\end{array}$

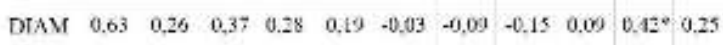

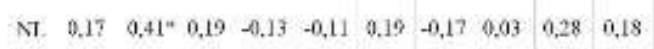

DMPA $0,65^{*}=0,13 \quad 0,19 \quad 0,17 * 0,55^{*} 0.44^{*} 0,91^{*} 0,74^{*} 0,44^{*}$

LA $0,66 \quad-0,06 \quad 0,05 \quad 0,2 \quad 0,27 \quad 0,57^{*} \quad 0,53^{*} \quad 0.24$

$\begin{array}{llllllll}R L & 0.29 & 0.02 & 0.25 & 0.21 & 0.16 & 0.01 & 0.14\end{array}$

DMR $0,5 y^{*} \quad-10,04 \quad 0,08 \quad 0,19 \quad 0,16 \quad 0,04$

$\begin{array}{llllll}\text { RA } & -0,05 & 0,22 & 0,25 & 0,01 & -0,01\end{array}$

NN $-0,57^{*}-0,63 *-0.22-0,31$

NCAP $\quad 0,75^{*}-0,25 \quad 0,03$

ANAP $0.4^{\circ} \quad 0,34$

NIT 0,12

Figure 1. Correlation between the analyzed variables in absence of inoculation $(A)$ and presence of inoculation. (B). ${ }^{*}$ Significant correlation at $5 \%$ probability

However, inoculated snap bean had 19 significant correlations, four of which were negative (Figure 1B). In this case, nodulation was negatively affected by the increase of DMPA, NCAP and ANAP. The nitrogen utilization efficiency was positively affected by height, diameter, DMPA, LA, and ANAP, while relative efficiency was affected by DMPA and NUE.

The nodulation was not able to influence the characteristics of the aerial part and the root system of the plant, demonstrated by the absence of a significant correlation of the number of nodules with these variables. Brito et al. (2015) and Soares et al. (2016), in which they affirm that nodulation and inoculation do not influence the vegetative growth of the plant, corroborate this.

For the efficiency of nitrogen use, it is possible to observe differences in correlation of variables as a function of inoculation. In uninoculated plants, NUE is influenced by MSPA and NAPA, so the choice of cultivars with these characteristics is more efficient. In this way, the cultivars Contender and Strike are the most recommended in planting without inoculation with $\mathrm{R}$. tropici.

\section{Conclusions}

The use of Rhizobium tropici does not interfere in the vegetative development of the snap bean until the flowering stage, wherein the cultivars Delinel, Jade and Stringless Green stand out for nodulation.

Inoculation is able to increase the number of nodes, specifies nodulation and nitrogen utilization efficiency, but reduces the nitrogen content and nitrogen by the cumulative shoot.

There is a negative correlation between the nodulation and the dry mass of the aerial part, nitrogen content and the nitrogen accumulated by the aerial part.

\section{Acknowledgments}

The State University of Goiás for research funding.

\section{References}


ALBUQUERQUE, H.C.; PEGORARO, R.F.; VIEIRA, N.M.B.; AMORIM, I.J.F.; KONDO, M.K. Capacidade nodulatória e características agronômicas de feijoeiros comuns submetidos à adubação molíbdica parcelada e nitrogenada. Revista Ciência Agronômica, v.43, n.2, p.214-221, 2012. http://dx.doi.org/10.1590/S180666902012000200002.

ALVARES C.A.; STAPE, J.L.; SENTELHAS, P.C.; DE MORAIS GONCALVES, J.L.; SPAROVEK G. Köppen's climate classification map for Brazil. Meteorologische Zeitschrift, v.22, n.6, p.711-728, 2013. http://dx.doi.org/10.1127/0941-2948/2013/0507.

BARRACLOUGH, P.B.; HOWARTH, J.R.; JONES, J.; LOPEZ-BELLIDO, R.; PARMAR, S.; SHEPHERD, C.E.; HAWKESFORD, M.J. Nitrogen efficiency of wheat: genotypic and environmental variation and prospects for improvement. European Journal of Agronomy, v.33, n.1, p.1-11, 2010. https://doi.org/10.1016/j.eja.2010.01.005.

CAMPANHARO, M.; LIRA JUNIOR, M.A.; NASCIMENTO, C.W.A.; STAMFORD, N.P.; FREIRE, F.J.; COSTA, J.V.T. Acidez do solo na fixação biológica de nitrogênio em feijoeiro comum. Revista Brasileira de Ciências Agrárias, v.5, n.3, p.285-290, 2010. https://doi.org/10.5039/agraria.v5i3a436.

CANCELLIER, E.L.; BARROS, H.B.; KISCHEL, E.; GONZAGA, L.A.M.; BRANDÃO, D.R.; FIDELIS, R.R. Eficiência agronômica no uso de nitrogênio mineral por cultivares de arroz de terras altas. Revista Brasileira de Ciências Agrárias, v.6, n.4, p.650-656, 2011. https://doi.org/10.5039/agraria.v6i4a1420.

CARMO, C.A.F.S.; ARAÚJO, W.S.; BERNARDI, A.C.C.; SALDANHA, M.F.C. Métodos de análise de tecidos vegetais utilizados na Embrapa Solos. Rio de Janeiro: Embrapa Solos, 2000. 41 p.

CERRO, P. DEL; PÉREZ-MONTAÑO, F.; GIL-SERRANO, A.; LÓPEZ-BAENA, F.J.; MEGÍAS, M.; HUNGRIA, M.; OLLERO, F.J. The Rhizobium tropici CIAT 899 NodD2 protein regulates the production of Nod factors under salt stress in a flavonoid independente manner. Nature, v.7, 2017. https://doi.org/10.1038/srep46712.

CHAGAS JUNIOR, A.F.; RAHMEIER, W.; FIDELIS, R.R.; SANTOS, G.R.; CHAGAS, L.F.B. Eficiência agronômica de estirpes de rizóbio inoculadas em feijão-caupi no Cerrado, Gurupi-TO. Revista Ciência Agronômica, v.41, n.4, p.709-714, 2010. http://dx.doi.org/10.1590/S1806-66902010000400027.

CHEKANAI, V.; CHIKOWO, R.; VANLAUWE, B. Response of common bean (Phaseolus vulgaris L.) to nitrogen, phosphorus and rhizobia inoculation across variable soils in Zimbabwe. Agriculture, Ecosystems and Environment, v.266, p.167-173, 2018. https://doi.org/10.1016/j.agee.2018.08.010.

FILGUEIRA, F.A.R. Novo manual de olericultura: agrotecnologia moderna na produção e comercialização de hortaliças. 3. ed. Viçosa: UFV, 2013. 421 p.

FONSECA, G.G.; OLIVEIRA, D.P.; SOARES, B.L.; FERREIRA, P.A.A.; TEIXEIRA, C.M.; MARTINS, F.A.D.; MOREIRA, F.M.S.; ANDRADE, M.J. Resposta de cultivares de feijoeiro-comum à inoculação das sementes com duas estirpes de rizóbio. Bioscience Journal, v.29, n.6, p.1778-1787, 2013. http://www.seer.ufu.br/index.php/biosciencejournal/article/view/21870. 10 Jan 2019.

FURLAN, F.F.; FREIRIA, G.H.; ALVES, G.A.C.; GOMES, G.R.; ALMEIDA, L.H.C.; FURLAN, M.F.; TAKAHASHI, L.S.A. Inoculação com estirpes de Rhizobium tropici em genótipos de feijão-vagem de crescimento determinado. Semina: Ciências Agrárias, v.37, n.6, p.3965-3972, 2016. https://doi.org/10.5433/16790359.2016v37n6p3965.

MATOSO, S.C.G.; KUSDRA, J.F. Nodulação e crescimento do feijoeiro em resposta à aplicação de molibdênio e inoculante rizobiano. Revista Brasileira de Engenharia Agrícola e Ambiental, v.18, n.6, p.567-573, 2014. http://www.scielo.br/pdf/rbeaa/v18n6/v18n6a01.pdf. 10 Jan 2019.

OLIVEIRA, R.C.; SBARDELOTTO, J.M. Nodulação em diferentes variedades de feijão inoculadas com

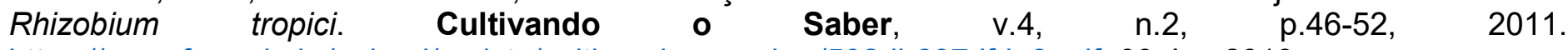
https://www.fag.edu.br/upload/revista/cultivando o saber/592db637dfde6.pdf. 09 Jan 2019. 
SANTOS, H.G.; JACOMINE, P.K.T.; ANJOS, L.H.C.; OLIVEIRA, V.A.; LUMRERAS, J.F.; COELHO, M.R.; ALMEIDA, J.A.; ARAUJO FILHO, J.C.; OLIVEIRA, J.B.; CUNHA, T.J.F. Sistema Brasileiro de Classificação de Solos. 5. ed. rev. e ampl. Brasília, DF: Embrapa, 2018. 590 p.

SIDDIQI, M.; GLASS, A.D.M. Utilization index: A modified approach to the estimation and comparison of nutriente utilization efficiency in plants. Journal Plant Nutrition, v.4, p. 289-302, 1981. https://doi.org/10.1080/01904168109362919.

SOARES, B.L.; FERREIRA, P.A.A.; RUFINI, M.; MARTINS, F.A.D.; OLIVEIRA, D.P.; REIS, R.P.; ANDRADE, M.J.B.; MOREIRA, F.M.S. Agronomic and Economic Efficiency of Common-Bean Inoculation with Rhizobia and Mineral Nitrogen Fertilization. Revista Brasileira de Ciência do Solo, v.40, 2016. https://doi.org/10.1590/18069657rbcs20150235.

TAIZ, L.; ZEIGER, E.; MOLLER, I.; MURPHY, A. Fisiologia e desenvolvimento vegetal. 6.ed. Porto Alegre: Artmed, 2017. 888 p.

TEIXEIRA, P.C.; DONAGEMMA, G.K.; FONTANA, A.; WENCESLAU, W.G. Manual de métodos de análise de solo. 3. ed. rev. e ampl. Brasília: Embrapa, 2017. 574 p.

TEIXEIRA FILHO, M.C.M.; BUZETTI, S.; ANDREOTTI, M.; ARF, O.; BENETT, C.G.S. Doses, fontes e épocas de aplicação de nitrogênio em trigo irrigado em plantio direto. Pesquisa Agropecuária Brasileira, v.45, n.8, p.797-804, 2010. http://dx.doi.org/10.1590/S0100-204X2010000800004.

VAZ, D.C.; MORAIS JÚNIOR, O.P.; PEIXOTO, N. Agro-morphological characterization and genetic divergence assessment in bush snap bean genotypes. Pesquisa Agropecuária Tropical, v.47, n.2, p.134-144, 2017. http://dx.doi.org/10.1590/1983-40632016v4743525.

VIEIRA, C.L.; FREITAS, A.D.; SILVA, A.F.; SAMPAIO, E.V.; ARAÚJO, M.S. Inoculação de variedades locais de feijão macassar com estirpes selecionadas de rizóbio. Revista Brasileira de Engenharia Agrícola e Ambiental, v.14, n.11, p.1170-1175, 2010. http://www.scielo.br/pdf/rbeaa/v14n11/v14n11a06.pdf. 13 Fev 2019.

YAGI, R.; ANDRADE, D.S.; WAURECK, A.; GOMES, J.C. Nodulações e produtividades de grãos de feijoeiros diante da adubação nitrogenada ou da inoculação com Rhizobium freirei. Revista Brasileira de Ciência do Solo, v.39, n.6, p.1661-1670, 2015. https://doi.org/10.1590/01000683rbcs20140342. 